\title{
WORD FORMATION PROCESSES IN ENGLISH NEW WORDS OF OXFORD ENGLISH DICTIONARY (OED) ONLINE
}

\author{
Elisa Ratih ${ }^{1}$, Rosalin Ismayoeng Gusdian ${ }^{1}$ \\ English Language Education Department, Faculty of Teacher Training and Education \\ University of Muhammadiyah Malang \\ email: rosalindedy@gmail.com
}

\begin{abstract}
The aims of this study were to identify the processes of word formation in English new words and to know which word formation processes were the most productive one(s). The researcher used qualitative research design in order to obtain the data from the document of OED online. OED online is the online dictionary which consists of list of English new words. Therefore, the research object was the lists of English new words from year 2012-2016. Document analysis was used as the instrument to collect the data. The data were presented in the form of table. The findings of this study showed that there are some processes in creating English new words, such as a) affixation, b) folk etymology, c) compounding, d) abbreviation, e) acronyms, f) borrowing, g) blending, h) clipping, i) back-formation. Besides, there are also found the double word formation processes, such as j) folk etymology + compounding, $\mathrm{k}$ ) compounding + affixation, $\mathrm{m}$ ) blending + affixation, $\mathrm{n}$ ) clipping + blending. The result showed that the most productive process of creating English new words was affixation.
\end{abstract}

Keywords: Word formation, process, English new words, OED online

\section{Introduction}

Word formation process is generally known as the phenomenon which is so close to human's life in the world. According to Trask (1997), word formation process is a way to construct new words from existing materials. Meanwhile, according to Hacken and Thomas (2013), word formation process is how to produce the new words based on the some rules. Besides, Plag (2003) stated that word formation process is the process to create new words from other words. From the explanation above, it can be concluded that word formation process is the way to construct new words from the existing words based on some rules. Word formation process can be productive and non-productive.

Bauer (1983) stated that word formation process will be productive if it is appropriate to use in the production of new materials. Meanwhile, the word formation process will be called as non-productive if it is not appropriate to use in the production of new materials. Therefore, it can be concluded that word formation process will be productive if it can be used to produce the new words.

The new words appear every year. According to Monitor (2017), a new word is created every 98 minutes or it can be said that a new word is created about 14.7 words per day. It is also stated that approximate estimation of words in English is 1,041,257.5 number of words by January 1, 2017.

According to Harley (2006), new words are the words which are built by manipulating the existing words. She also stated that the new words are built by some 
processes which are affixation, blending, compounding which are more productive to create the new words. Moreover, Pliatsikas et al. (2014) stated that the new words are based on derivational morphological process. However, they found a disambiguation process between noun and verb stems. Besides, Xhina (2013) stated that the word formation process has two common processes which are derivation and compounding in English and Albanian.

Furthermore, Mustafa et al.(2015) stated that word formation processes which are very common to use by Malaysian Facebook users are abbreviation, blending, and the use of emoticons while they communicate in Facebook every day. Then, Wei and Wenyu (2014) said, "The most frequently occurring word-formation process of netspeak neologisms is compounding, subsequently, blending, affixation, old words with new meaning, acronyms, conversion, and clipping". However, from the studies above, the most productive of word formation processes is still unclear.

Meanwhile, Bizhkenova et al. (2017) stated that the most productive of word formation are prefix-derivation, suffix-derivation, prefix-suffix derivation, konfixderivation, external lexemes+internal lexemes, internal lexemes+external lexemes, konfix+internal lexemes which are called as hybridization (the compounding of English stems into the German words list). Moreover, Montero-Fleta (2011) stated that the most productive of word formation processes in scientific registers is suffixes.

The new words will be listed in dictionaries. One of them is Oxford English Dictionary (OED). Oxford English Dictionary is one of dictionaries which is famous in the world. In 1928, this dictionary consisted over 400.000 words. In 2011, this dictionary consisted over 66.500 headwords. The new OED was programmed to consist over 6.400 pages. It shows that OED contains many new words of English in every year.

Montero-Fleta (2011) used the OED in her study to find the words which contain of suffix. Besides, Nishimoto (2014) also used OED to check the prefixed forms and compounds. It shows that OED is one of the objects which can be used in investigating about word formation processes.

From the several above mentioned studies, it can be seen that none of the studies investigated about word formation process in English new words of online dictionary. Therefore, to fill this gap, this study will investigate the word formation process in English new words of online dictionary which is OED online.

\section{Method}

This study was designed as qualitative research because it presents the data by describing the processes of word formation in creating new words. Moreover, the qualitative research design was chosen in this study because the aims of this study were to know what word formation processes in English new words were and to know which word formation process is more productive one(s). Besides, the researcher used case study as a design to analyze the word formation processes in English new words of OED online. The researcher used Oxford English dictionary online as the object of the research. The object can be accessed in http://public.oed.com/the-oed-today/recent-updates-to-the-oed/. In this website, there

CELTIC: A Journal of Culture, English Language Teaching, Literature \& Linguistics PISSN 2356-0401 EISSN 2621-9158

VOLUME 5 NO 22018 
are the lists of English new words in every year. In this research, the researcher analyzed the lists of English new words from year 2012-2016 by using systematic random sampling. The researcher randomly took 10 English new words as the samples based on each alphabetical initials from each year. For example, initials with A was taken as many as 10 words, initials with B was taken as many as 10 words, and so on. Besides, the researcher used document as the instrument to collect the data.

Furthermore, the researcher sorted out the samples of new words from year 2012-2016. After the researcher sorted out the samples of new words, the researcher gave a code or grouped the new words based on the same year and the same alphabet. For example, the new words in year 2012 were grouped in the same table.

After the researcher got the coding, the researcher organized it into a table. Moreover, the researcher validated the data to the expert who is linguistics lecturer in University of Muhammadiyah Malang. Then, the researcher compared the results with the theories. In the last step, the researcher made a conclusion.

\section{Findings and discussion}

The findings of this study showed that there are some processes in creating English new words, such as a) affixation, b) folk etymology, c) compounding, d) abbreviation, e) acronyms, f) borrowing, g) blending, h) clipping, i) back-formation. Besides, there are also found the double word formation processes, such as $\mathrm{j}$ ) folk etymology + compounding, k) compounding + affixation, m) blending + affixation, n) clipping + blending.

\section{a. Affixation}

Affixation has some types, such as prefix, suffix, infixes, and circumfixes. Then, in the findings, the types of affixation found are prefix, suffix, and circumfixes.

i. Prefix

For example, autocyclic. In the word 'autocylic', the stem iscylic. It undergoes to affixation because it is added by prefix auto-. Some other examples are biomethane, cycloheptane, cyclohexane, etc.

ii. Suffix

For example, accretor. In the word 'accretor', the stem is accrete. It undergoes to affixation because it is added by suffix -or. Some other examples are Aftonian, arcticized, bustler, etc.

iii. Circumfixes

For example, afrofuturism. In the word 'afrofuturism', the stem is future. It undergoes to cirumfixes because it is added by prefix afro- and suffix -ism. Some other examples are afrofuturist, anti-unionism.

\section{b. Borrowing}

Borrowing is how to borrow the words from other language without any changing. Theborrowing process which found in the findings are kinara, emoji, Naqada, mabuhay, angpow. The word 'kinara' is borrowed from Swahili which means 'candleholder'. Besides, the word 'Naqada' is borrowed from Arabic which means 'the site of archaeological in Egyptian governorate of 
Qena'. The word 'mabuhay' is borrowed from Tagalog which means 'greeting'. Then, the word 'angpow' is borrowed from Chinese. From the explanation above, it can be concluded that those new words are borrowed from another language without any changing.

\section{c.Folk Etymology}

Folk etymology is a little bit same with borrowing process. Folk etymology appeared because of historical story. It is because the speaker has different interpretation of the form. Therefore, the speaker changes the form or the pronounciation. However, in borrowing process, it is just borrowed witout any changing. The examples of folk etymology process which found are apastron, falcial, ironice, fleishig, quadruple, etc. The word 'apastron' is made from

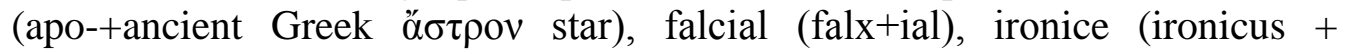
classical Latin - $\overline{\mathrm{e}}$ ), fleishig (from Yiddish fleyshik), quadruple (Quadruples). From the explanation above, it can be seen that those new words are coming by borrowing from another language or by adding another language, such as classical Latin or ancient Greek for instance.

\section{d. Compounding}

Besides, the new words which are made by compounding process are battleground, audio dub, aussieland, batchmate, hackboat, etc. For detailed data, see appendix 1. The word 'battleground' is made from (battle+ground), audio dub (audio+dub), aussieland (Aussie+land), batchmate (batch+mate),hackboat (hack+boat). From the explanation above, it can be seen that those new words are coming by combining two words become a word.

\section{e. Abbreviation}

Furthermore, the new words which are made by abbreviation process are CABG, Lw, Rt. Hon, SCBU, MRS, etc. CABG is 'Coronary Artery Bypass Graft', Lwis 'Long wave', Rt. Hon is 'Right Hon', SCBU is 'Special Care Baby Unit', MRS is 'Magnetic Resonance Spectroscopy'. From the explanation above, it can be seen that it should be spoken letter by letter which is called as abbreviation.

\section{f. Acronyms}

Besides, the new words which are made by acronyms process are Captcha, Osha, ISA, YOLO, etc. Captcha is coming from Completely Automated Public Turing test to tell Computers and Humans Apart, Osha is coming from Occupational Safety and Health Administration, ISA is coming from Industry Standard Architecture, YOLO is coming from You Only Live Once. Those are called as acronyms because the words can be read without speaking it letter by letter.

\section{g. Blending}

The blending processes which found in the findings are cybercast, digipak, irone, chugger, backronym, brunello, etc. The word 'cybercast' is coming from cyber+broadcast. First, the word 'broadcast' is clipped become 'cast'. Then, it 
combines with cyber. It can be concluded that blending has two processes which are clipping and compounding. Then it blends into a word. Some other examples are digipak, irone, clicktivist, etc.

\section{h. Clipping}

The new words which are created from clipping process are dom, disco, demo, syst, Scandi, etc. For detailed data, see appendix 1. The wod 'dom' is dominus, the word 'disco' is discotheque, the word 'syst' is system, the word 'Scandi' is Scandinavian. Those words are created by cutting the back which is called as final clipping. Therefore, it can be concluded that final clipping is the dominant type of clipping in creating a new word.

\section{i. Back-Formation}

Back-formation is a little bit same with clipping. However, in back-formation, it can change the part of speech. While, in clipping, it does not change the part of speech.The new word which are created by back-formation process is gank. It is coming from 'gangster'. It is the only back-formation process which was found in 2012-2016. From the word 'gank', it can be seen that the back is deleted and it changes into another one.

\section{j. Double Word-Formation Process}

Double word-formation process is how to combine two derivational processes into a word. In the findings, the double word-formation processes found are:

\section{(i) Folk Etymology+Compounding}

The new words can be created by folk etymology+compounding process. It means that there are two processes which are folk etymology and compounding. For example, historiosophy. It is coming from historio (from Greek) +sophy (from Greek). It can be seen that those word are coming from Greek and it combines into a word.

\section{(ii) Compounding+Affixation}

The new words can be created by compounding+affixation. It means that the new words are created by two processes. For example, live-blogging, oversighting, beatboxer, dayworker, hardrocker, etc. For detailed data, see appendix 1. The word 'live-blogging' is coming from live+blog+ing. The word 'oversighting' is coming from over+sight + ing. The word 'beatboxer' is coming from beat+box+er. The word 'dayworker' is coming from day+work+er. The word 'hardrocker' is coming from hard+rock+er.

\section{(iii) Blending+Affixation}

Furthermore, the new words can also be created by blending+affixation. For example, syntagmatics. It is coming from syntax+pragmatic+s. The word 'syntax+pragmatic' is created by blending. Then, it is added by 's' as the suffix affixation.

\section{(iv) Clipping+Blending}

Then, clipping+blending process can also create a new word. For example, the word 'd-line'. It is coming from defensive line. It can be seen that the word 
defensive stands for ' $d$ '. It can be seen that it is clipping process, then it blends with word 'line'

\section{Word Formation Processes in 2012}

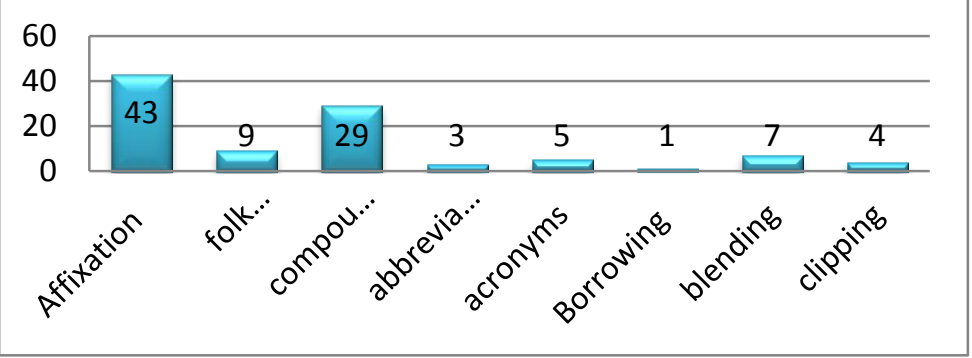

Chart 4.1.2.1

From the chart above, it can be seen that the most productive process of English new words in 2012 is affixation which is 43 words. The examples of affixation in 2012 are acrretor, Aftonian, autocyclic, allotransplant, algesic, etc. The second process which is dominant process in 2012 is compounding, which is 29 words. Then, folk etymology was found as many as 9 words. Furthermore, blending was found as many as 7 words. Moreover, the less productive processes are acronyms which is 5 words, clipping as many as 4 words, and abbreviation as many as 3 words. Meanwhile, the unproductive process of English new words in 2012 is borrowing, which is 1 word only. The example of borrowing process in 2012 is kinara.

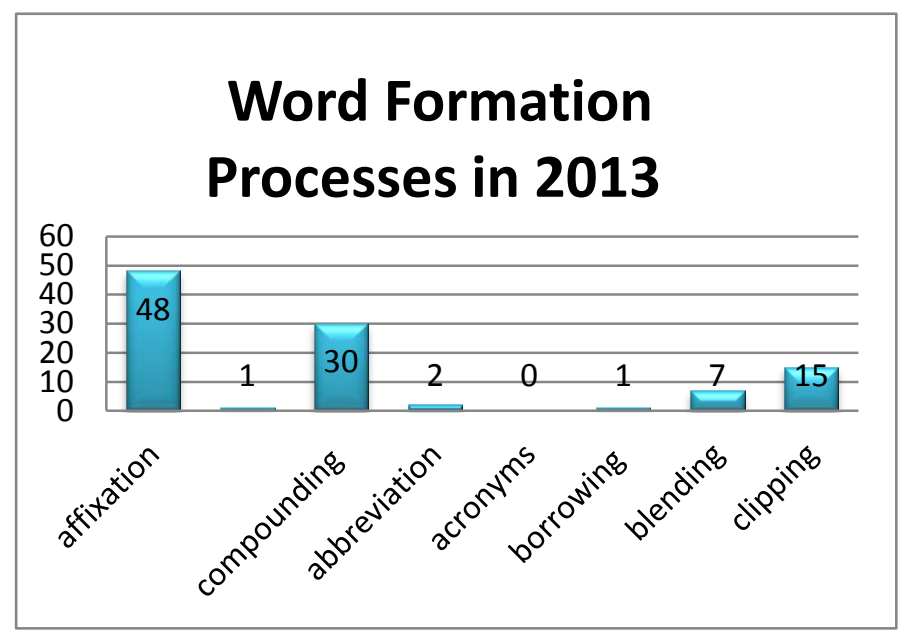

Chart 4.1.2.2

From the chart above, it can be seen that the most productive process of English new words in 2012 is affixation, which is 48 words. The examples of affixation in 
2013 are audiophilia,archicortical,arabesquenes, andic, aplitic, etc. The second process which is dominant process in 2013 is compounding, which is 30 words. Then, clipping was found as many as 15 words, blending was found as many as 7 words. Furthermore, the less productive processes are abbreviation which is 2 words, borrowing and folk etymology which is 1 word.Then, theunproductive process of English new words in 2013 is acronyms.

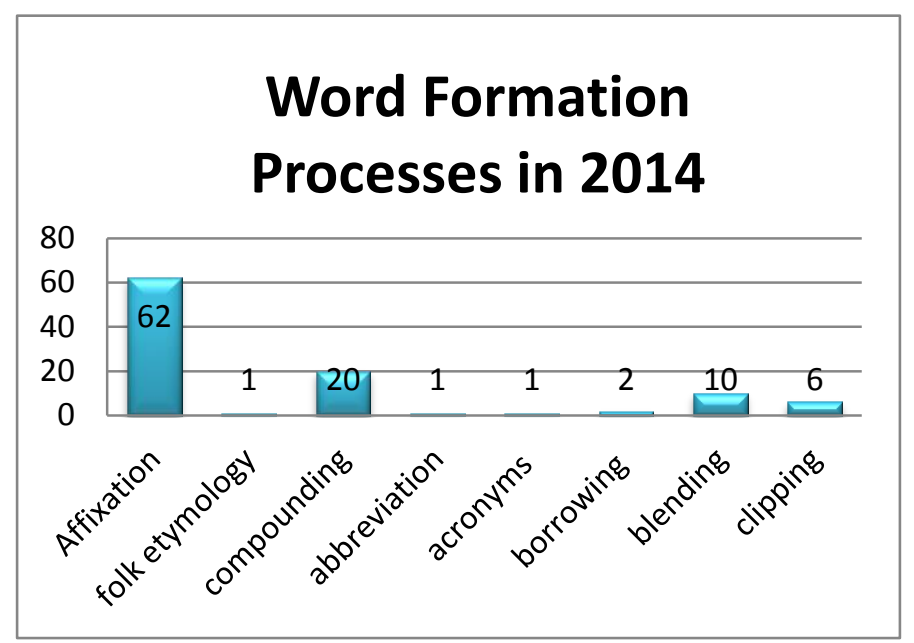

Chart 4.1.2.3

From the chart above, it can be seen that the most productive process of English new words in 2014 is affixation, which is 62 words. The examples of affixation in 2014 are allobarbital,authorhood, anthropocene, apotheotic, bestie, etc. The second process which is dominant process in 2014 is compounding, which is 20 words. Blending was found as many as 10 words, and clipping was found as many as 6 words. Meanwhile, the less productive processes of English new words in 2014 are borrowing which is 2 words, acronyms, folk etymology, and abbreviation which are 1 word only. 


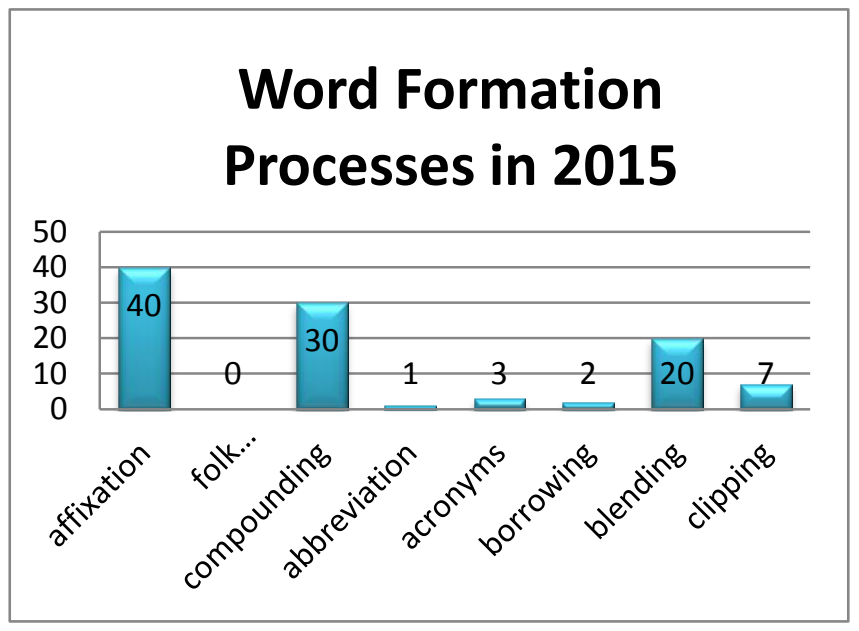

Chart 4.1.2.4

From the chart above, it can be seen that the most productive process of English new words in 2015 is affixation, which is 40 words. The examples of affixation in 2015 are avelling, anti-unionism, Antonite, belayer, biomethane, etc. The second process which is dominant process in 2015 is compounding, which is 30 words.Blending processes was frequent found as many as 20 words. Clipping was found as many as 7 words. Meanwhile, the less productive processes are abbreviation which is 1 word, acronyms which is 3 words, and borrowing which is 2 words. Then, the unproductive process of English new words in 2015 is folk etymology.

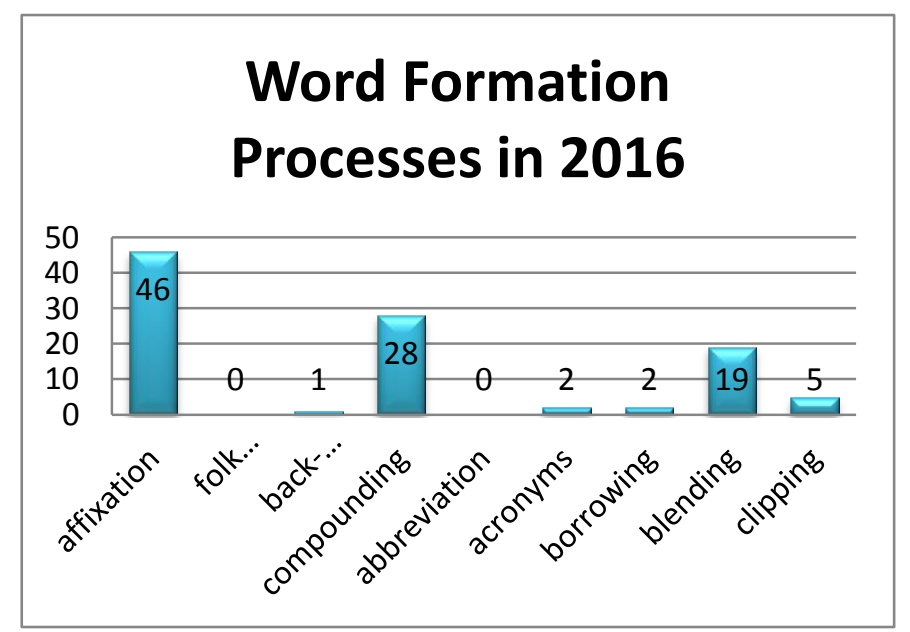

Chart 4.1.2.5 
From the chart above, it can be seen that the most productive process of English new words in 2016 is affixation, which is 46 words. The examples of affixation in 2016 are afrofuturism, afrofuturist, brunchy, browsability, botrytized, etc. The second process which is dominant process in 2016 is compounding, which is 28 words. Blending processes were found as many as 19 words. Meanwhile, the less productive processes are clipping was found as many as 7 words. Besides, the less productive processes are back-formation was found as many as 1 word, acronyms as many as 2 words, and borrowing as many as 2 words. Meanwhile, the unproductive processes in 2016 are folk etymology and abbreviation.

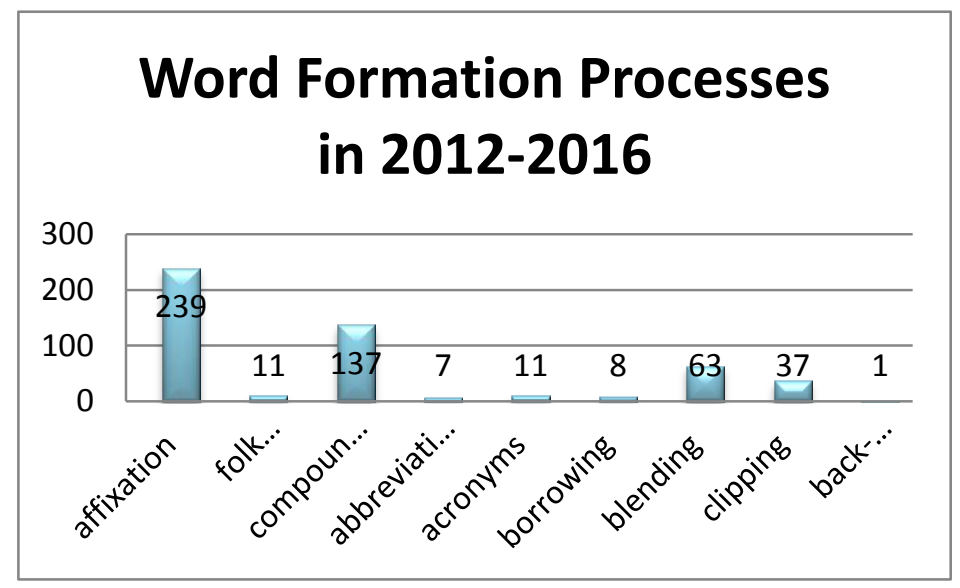

Chart 4.1.2.6

From the chart above, it can be seen that the processes of English new words in 2012-2016 are coming from affixation (239 words), folk etymology (11 words), compounding (137 words), abbreviation ( 7 words), acronyms (11 words), borrowing ( 8 words), blending (63 words), clipping (37 words), and back-formation ( 1 word). Therefore, it can be concluded that the most productive process in year 2012-2016 is affixation.

In the findings, it can be seen that affixation is the most productive process in creating a new word. It supports Harley's statement (2006) which stated that affixation is one of the main ways new words to enter the language. Furthermore, it also supports the statement of Plag (2002) which stated that the new verbs in English can be made from affixes. From the findings, it can be seen that there are 239 new words are created by affixation process. Therefore, affixation becomes the most productive process of new words in English to enter the language. Furthermore, the findings found that backformation process is unproductive process. It is because only 1 backformation process found in year 2012-2016. It supports Aronoff's (2011) who states that backformation is the word formation process which is not a productive process. Moreover, the researcher found the interesting findings, such as double word formation process in creating the new words which is not stated in previous research. 
The double word formation process is how to combine two derivational processes into a word. In the findings, the double word formation processes found as folk etymology+compounding,compounding+affixation, blending+affixation, and clipping+blending.

\section{Conclusion}

Based on findings and discussion, it can be concluded that there are some processes which found in English new words of Oxford English Dictionary (OED) online, which are affixation (accretor, autocyclic, assimilativeness, etc), folk etymology (apastron, falcial, geophagia, etc), compounding (battleground, busgirl, broadband, etc), abbreviation (CABG, H-R diagram, MRS, etc), acronyms (captcha, FLOP, LARP, etc), borrowing (kinara, emoji, korona, etc), blending (dataveillance, femcee, gaysoc, etc), clipping (dom, eff, fem, etc), and back-formation (gank). Moreover, the researcher found the interesting findings, such as double word formation process in creating the new words, such as folk etymology + compounding, compounding + affixation, blending + affixation, and clipping + blending. Then, the most productive processin English new words is affixation process. It means that affixation is the dominant process of creating English new words.

\section{References}

A.E. Bizhkenova, S. (2017). Neologisms in Present-Day German: Investigation Into. Journal of Fundamental and Applied Science, 982-996.

Admin. (2012, April). Blending. Retrieved February 25, 2018, from British Council BBC: https://www.teachingenglish.org.uk/article/blending

Alwasilah, A. C. (2011). Beberapa Mazhab dan Dikotomi Teori Linguistik. Bandung: Angkasa.

Astalin, D. P. (2013). Qualitative Research Designs: A Conceptual Framework. International Journal of Social Science \& Interdisciplinary Research, 119.

Bauer, L. (2006). Word Formation. Encyclopedia of Language \&Linguistics (Second Edition), 632-633.

Chaer, D. A. (2003). Linguistik Umum. Jakarta: PT Asdi Mahasatya.

Christos Pliatsikas, Linda Wheeldon, Aditi Lahiri, Peter C. Hansen. (2014). Processing of zero-derived words in English: An fMRI investiogation. Neuropsychologia, 47-53.

Dictionaries, O. (2012, April 26). Oxford Dictionaries. Retrieved January 13, 2018, from (C) 2018 Oxford University Press: 
https://blog.oxforddictionaries.com/2012/04/26/a-short-history-of-oxforddictionaries/

Dictionaries, O. (n.d.). Oxford Dictionaries. Retrieved January 13, 2018, from (C 2018 Oxford University Press: https://www.oxforddictionaries.com/ourstory/history

Harley, H. (2006). English Words: a Linguistic Introduction. 7th ed. Oxford: Blackwell.

Mark Aronoff, K. F. (2011). What is Morphology? 2nd Edition. UK: WileyBlackwell.

Merriam-Webster. (2018, February 5). Dictionary. Retrieved February 16, 2018, from https://www.merriam-webster.com/dictionary/dictionary

Meyer, C. F. (2009). Introducing English Linguistics. United States of America: Cambridge University Press.

Micahel Quinn Patton, Michael Cochran. (2002). A Guide to Using Qualitative Research Methodology.

Monitor, G. L. (2017, November 12). Global Language Monitor. Retrieved February 2, 2018, from Number of Words in the English Language: https://www.languagemonitor.com/global-english/number-of-words-in-theenglish-language-1041257-5/

Montero-Fleta, B. (2011). Suffixes in word-formation. LSP Journal , 4-14.

Mustafa, Kandasamy, Yasin. (2015). An Analysis of Word Formation Process in Everyday Communication on Facebook. International Journal of Education and Research, 261-274.

Nishimoto, E. (2004). Defining New Words in Corpus Data: Productivity of English Suffixes in the British National Corpus.

Pateda, D. M. (2015). Linguistik Sebuah Pengantar. Bandung: CV Angkasa.

Pius Ten Hacken, Andrea Abel, Judith Knapp. (2006). Word Formation in an Electronic Learner's Dictionary: ELDIT. International Journal of Lexicography, Volume 19, Issue 3, 243-256.

Pius Ten Hacken, Claire Thomas. (2013). The Semantics of Word Formation and Lexicalization. Edinburgh: Edinburgh University Press.

Plag, I. (2003). Word-Formation in English. Cambridge: Cambridge University Press.

Saussure, F. D. (2013). Course in General Linguistics. Great Britain: A\&C Black. 
Sugiyono. (2008). Metode Penelitian Kuantitatif dan Kualitatif dan R\&D. Bandung: Alfabeta.

Wardaugh, R. (2006). An Introduction to Sociolinguistics, 5th Edition. Blackwell Publishing Ltd.

Wei Liu, W. L. (2014). Analysis on the Word-formation of English Netspeak Neologism. Journal of Arts \& Humanities, 22-30.

Xhina, O. (2013). The Enrichment of the Vocabulary through Word Formation Processes in both English and Albanian Languages. Academic Journal of Interdisciplinary Stuides , 273-282.

Yule, G. (2010). The Study of Language, 4th ed. Cambridge: Cambridge University Press. 